\title{
REVIEWS AND ANNOUNCEMENTS
}

Anatomie europaischer Holzer. Anatomy of European woods. - Fritz Hans Schweingruber, 802 pp., illus., 1990. Publication of the Swiss Federal Institute for Forest, Snow and Landscape Research. Available from Buch handlung Paul Haupt, Falkenplatz 14, CH-3001 Bern, Switzerland. Price: SFr. 140.00 , DM 160.00 , US\$ c. 100.00 .

This is a remarkable wood anatomical atlas for European plants from a wide range of habitats. With 802 pages, measuring approximately $5 \mathrm{~cm}$ in thickness, and weighing over 3.16 kilograms, it is both literally and figuratively a massive work. It represents a tremendous amount of original work as the author personally collected, sectioned, and photographed the samples of the over 700 species of trees, shrubs, and dwarf shrubs which are described and illustrated. Given that archaeologists, palaeobotanists, and forensic scientists often are interested in the identification of woody fragments from shrubs and dwarf shrubs as well as from trees, this reference work is valuable for a wide audience. Among the stated objectives is the intention to present "the anatomical variability of the woody plants examined" and to show "how greatly the [anatomy] can vary within one individual." To do so, many photomicrographs per species or species and genus group are used; these photographs [in total 3473 !!] are of high quality.

Students and colleagues were impressed by this book with its many photographs, and, to put it in Americanese, local first reactions uniformly were of the 'Wow!!' variety. The question following the 'Wow' reaction usually was: "But, how much does this cost?!", and all were pleasantly surprised and considered the book to be very reasonably priced. So if you want to pictorially impress friends and colleagues with how lovely wood anatomy can be, or show a particular anatomical feature to a student (and surely most of us would), this book with its 3473 (!) photographs should be kept in a readily accessible place on your bookshelf.

Not only are there pictures, but for each species/species group/genus, there is a brief description of the 'unit's' anatomy, and useful comments on key characters and problems of identifying that 'unit'. When deemed appropriate, there are tables comparing the salient features of similar species or genera. One minor quibble with the 'species' section, although the information is available elsewhere it would have been nice to have mentioned the habit of the species in the text opposite the description. The text is in side-byside German and English versions. In the introduction microscopic features are defined. There are a few places where the English translation seems a little awkward, or the definition seems not quite accurate (e.g. vestured pits are defined as "deposits are irregularly arranged in the pit aperture"), but given the pictures that is the type of remark that may be deserving of a 'so what?' response. Additionally, there is a sensible key. As an overview to the ecologic significance of the vast array of wood structural types in the European flora, there is an elegantly written final chapter by Pieter Baas on ecology and wood anatomy (comparable to the much-cited Baas, P. \& F. H. Schweingruber. 1987. Ecological trends in the wood anatomy of trees, shrubs and climbers from Europe. IAWA Bull. n.s. 8: 245-274). In summary, this is a most impressive book, the kind that leaves you absolutely awed by the amount of work that went into its preparation and execution.

E.A. Wheeler

\section{Dendrophysica - Wissen über die Baum- Natur. Versuch einer dialektischen Dar- stellung. Hans Heinrich Bosshard, 230 pp., 1990. Birkhäuser Verlag, Basel, Boston, Berlin. Price DM 54.00, SFr. 48.00 (hard- back). \\ The subtitle of this unusual book will soon take away any erring thoughts the word Dendrophysica may inspire in the innocent mind: not the physical properties of trees but our knowledge and understanding of the na- ture of trees are its subject matter. Professor Bosshard wrote the book instead of giving a valedictory lecture on the occasion of his re-}

